\title{
Temporal Conditions, Permanent Values: Africa and Literary Idea
}

\author{
Dennis Aiyejina \\ Department of Theatre and Media Arts, Ambrose Alli University, Ekpoma, Nigeria
}

KEYWORDS Temporal. Transcendence. Spiritual. Salutary. Values.

\begin{abstract}
The dilemma of postcolonial Africa, her writers and peoples is the problem of having to develop under two conflicting traditions: the African tradition and western culture. This dilemma obviously is occasioned by Africa's colonial and neocolonial experiences, which tend to deprive literary production in the continent spirituality and transcendental value.The colonial and neocolonial realities represent the temporal conditions from which the postcolonial African writer seeks to liberate, while his relegated African cultural heritage represent the missing absent order that is needed to give a meaning and salutary value to his essence. This paper therefore explicates the extent to which the postcolonial African writers attempt to recover the absent traditional insights and difference in postcolonial African literature in order to give it a transcendental value.
\end{abstract}

\section{INTRODUCTION}

To appreciate fully the dilemma of most African countries today is to understand the full import of what Frantz Fanon (1961) means, when he says that:

It is true to say that independence has brought moral compensation to colonized peoples, and has established their dignity. But they have not yet had time to elaborate a society, or to build up and affirm values. The warming, light-giving centre where man and citizen develop and enrich their experience in wider and still wider fields does not yet exist. Set in a kind of irresolution, such men persuade themselves fairly easily that everything is going to be decided elsewhere, for everybody, at the same time.

(Emphasis mine, 64)

The "elsewhere" in the above extract is Europe or in a deeper sense, "heaven", where our reward lies in store. Africa's ultimate goal is to be turned into another Europe. She thus has left her destiny in the hands of European gods - spiritual and temporal, enjoying since independence only instability and discontent-ment, a twin feature that is the only permanent value of western metaphysics. That is why African literature has a duty to search for and create a situation of permanence in this complex situation of importance.

\section{THE STRUCTURE AND VALUE OF SOME AFRICAN LITERARY WORKS}

Literature by its very nature is a structure of permanence, which defines a continuous usefulness for man. Historically, literature was the first ideological form, which Plato (nism) sought to dismantle its power. Still, historicism in literary discourse affirms a relevance and the need to understand the changing contexts of a milieu's norms and values - which in particular had helped in creating and defining literary forms as ideologies in Africa since the 1930s when Negritude literature was used as neo-colonialist discourse.

What is therefore crucial in African literature is to situate post-colonialism as a time-image and as a "reconstruction" which arrests disintegration and disillusionment in post-modern or multinational African capitals. Simon During (1987) in "Post-modernism or Post-colonialism Today" asserts correctly that by naming the loss of critical distance in the world today, post-modernity names also the "delegitimation of those categories by which a cultural centre or a socio-economic base might be identified" (32). This absence implies the presence of another absence especially in modern and postmodern African literature; that is, the underlying cultural image which is presently absent in the education of the African. That is why Ngugi Wa Thiong'o (1981), in Writers in Politics, stresses the point that a nation's literature should be the "sum total of the products of many individuals in that so

Not surprisingly, the reception of literary ideas is poor. The high level of illiteracy consciously allowed to stay high by our misguided leaders does not help matters; worse still is the confusing notion shared by members of the elite class that humanistic values are irrelevant in the contemporary quest for scientific knowledge. In 
short, deprived of (African) literary education, ill advised by brainwashed neocolonialist advisers, our leaders have difficulty in benefiting from the very profound ideas of literature, philosophy and history. In turn, the society suffers adversely from the poverty of our leaders' vision and projections.

This is a very unfortunate situation in a society where literature more than any other humanistic science produces structures of salutary possibilities, beside the fact that narrative power for Less Developed Countries is the best substitute for the lack of information technology enjoyed by Developed Countries. The truth is that for Africa, literature is more than history (experience) and philosophy (imagination). It is more fundamentally, perception (vision and ideology) required for the technological and political growth of the nation.

Because literature is ideology, the tendency is to limit its perceptive structure to themes. Yet more than anything, form (of discourse) is the primary feature of perception, and it is the last feature of any society, period or tradition. Societies have, thus, always placed great premium on quality literature because it is the only monument that sings about an age to posterity (see Shakespeare's "Sonnet 55"). Good literature to state the obvious is good form. Any good form, innovative and fresh, is the hallmark of culture and civilization. For instance, Post-colonial African needed the works of Senghor, Achebe, Okigbo, Soyinka and others at a particular time in history to impress upon Europe that Africans have minds. What is often forgotten in the contemplation of the works of these authors is the fact that it is their (commitment to) craft that is foregrounded.

In an ideological sense therefore, literary form defines the nature of the artist's society as well as the way the artist perceives order or disorder in a society. A poem with a neat structural arrangement may deal with a subject of disorder in order to show how a structural order can reflect and have clearly demonstrated the necessity of arresting the backsliding movement of society through a paradox of confronting the reality of evil in man. Yet these metaphorical confrontations with evil possess, ironically a religious/spiritual emptiness, which has rendered them suspect in Africa.

Therefore the next course to follow is to revert to another kind of ideological approach that could best contextualize the post-modern structures of our society as well as the persistent neocolonial attitudes of African leaders. This would also determine how the salutary themes, which arise from post-modern literature could form a basis of African political thought and ideology.

In a way, the works of our successful writersSoyinka, Achebe, Okigbo, Laye and Okpewhoprovide us a clear-cut path of approach. That is any African value, must be seen in terms of its cultural relevance; and if any ideological position is to be arrived at, it must be seen through culturally integrative forces of values. In other words, if neocolonialist argument in literature is geared towards an understanding of how Africans became slaves of foreign values, post-colonialist thrusts in literature then seek to recover these lost values which are largely responsible for the continuous disintegration of African nations.

One of such values is the African metaphysics of transcendence, which in practical everyday experience has provided a more reliable source than the imported western and Arabic metaphysics. While Camara Laye in all his works reactivated the spiritual force which lies behind every social and economic activity in Africa, it is Achebe more than any other African writer, especially in Arrow of God, where according to Soyinka (1976):

The struggle among the gods has been placed squarely in the province of the political, and although the spiritual and the mysterious are never absent or invalidated - certainly the affective or responsive in the lives of the community is constantly used to reinforce this dimension of reality. (89)

who has shown how the pressure of colonialism can make a society an instrument of the subversion of its own god. T. S. Eliot in "Journey of the Magi" reflects the consequence of such an abominable act:

But no longer at ease here, in the old dispensation, with an alien people clutching their gods I should be glad of another death.

Nevertheless, despite the well-planned dethronement of the African god, Ulu, it is incontestable that allowing a strange god to take over is the greatest tragedy of the Igbo community. According to Soyinka by secularizing the African god while deifying the Christian God, Achebe himself becomes the arrow of the deconstruction of the Igbo being and becoming:

The strongest argument in favour of a divine factor in the life of Umuaro is deliberately 
subverted by impure associations insinuated through the manipulations of language, contradicting situations, or the preponderant claims of secular wisdom.

(Soyinka 1976: 89)

Absent order indicates how that absence can be recreated. This is the case with Achebe's, Soyinka's, Osundare's and Armah's works where infertility and disintegration are packaged beautifully in well-wrought structures. On the other hand, a loose structural arrangement could be a signification of a certain kind of rigidity in the societal structure. Also, as it is evidenced in the poems of some "fourth generation" Nigerian poetsUche Nduka, Afam Akeh, Onookome Okome, Olu Oguibe etc.-chaotic structural arrangement is a symbolic reflection of a chaotic society.

In essence, if literary form is a permanent cultural value, then it ought to define for us deeper spiritual and ideological values. It is true as Michael Echeruo has argued in The Conditioned Imagination that "a people cannot but read and judge literature in the light of what may be called their particular historical and metaphysical situation" (1978:3). The contrary may only be the case if our own historical situation, especially colonialism and neocolonialism, has produced for us an alien metaphysical situation. Our value has ceased to be African and has instead become a monster-creation that is neither African nor Western.

This in a way explains part of the problem of the reception of salutary values of literature by our leaders who are expected in turn to convert them to beneficial structures. Worse still is the dearth of a truly African metaphysic in some of the ideological positions of our writers and critics. Indeed, two ideological types can be traced in the course of modern African literature: Negritude and Marxist ideologies. Both ideologies are somewhat identical in the sense that both struggle with the dialectics of rediscovery and the aesthetics of rewriting and rereading of texts, especially of colonial texts in order to achieve a new African vision in the postcolonial and postmodern Africa.

\section{THE FAILURE OF IDEOLOGIES AND THIER IMPACT ON THE SOLUTARY VALUES OF AFRICAN LITERATURE}

The failure of both Negritude and Marxist ideologies stems from the fact that they lack spiritual force. Marxism collapsed in Europe because of its insistence on only a materialist truth than on a duality of both the material and the spiritual. Also, Negritude aesthetics failed to carry along a large section of Africa because its poetic truth is merely an assertion of the otherness, which Europeans tended to obliterate. Meanwhile one of the otherness, which was completely subverted by Colonialism, is the spiritual force behind African systems. Charles I. Glicksberg thus shows, even though in a different context that:

Without the presence of God, even if only imminent in the heart of creation, without the horizon of the absolute, the dimension of the eternal, the writer beholds a world no longer held together and transfigured by the sense of the divine. It is charged, alas, into a bare, alien, desolute universe of sense data. (1985:139)

Again, according to Soyinka, the works of Senghor, Birago Diop and Oyono have clearly shown that Negritude literature "provided both a life-line along which the dissociated individual could be pulled back to the source of his metrical essence, and offered a prospect for the cominginto-being of new black social entities" (1976: 64). The same can be said of the works of great socialist writers like Armah, Iyayi, Ngugi, Ousmane and Osundare. The dethronement of African gods and their replacement with European gods are the greatest pull-offs of colonialism. It was a fact that signaled the disintegration, which we are still experiencing today. The disintegration of Umuaro on one hand, and that of Ezeulu and Ulu on the other is a classic symbolization of the disintegration of society, man and god which is still going on in Africa.

In Christopher Okigbo's poetic collection, Labyrinths (1970), he signaled in "Four Canzones" the temporalness, which permeates the fabric of the African world. The disturbing climate of frustration and pain motivated (and forced) the prodigal - protagonist of the poem to seek his spiritual heritage in "Heavensgate". Thereafter, he continues to retrace his steps spiritually in subsequent poems trying hard in the process to find a way of blending spiritual commitment with social relevance, especially how to accept a more committed role as a poet prophet of his society. Poetry or the religion symbolized in the goddess Idoto has given him the mandate to play a combination of responsible religious and political roles in his society. But 
the clash between foreign and local values as evinced in "Limits", "Distances", "Silences" C.

\section{THE WAY FORWARD IN AFRICAN LITERATURE}

Continuous regression not withstanding, Soyinka feels that gains can be made if the struggle for creativity - political and socioeconomic growth of the African world - is given a purely spiritual backing. For Soyinka, the values, which are the qualities, demonstrated by the Yoruba god, Ogun, in the drama of creating a communication link between man and the gods, are the qualities necessary for the continual regeneration of the society. These qualities, which include the will to survive and inventive-ness are divine, and Soyinka's protagonists in all his works have shown that any temporal reductivity will prove disastrous for both the protagonists and the society. In short, the hero of our African world should be nothing short of a god. That explains why Soyinka's characters who insist on probity and fertility become maimed or mad or suffer imprisonment and rejection.

Still, for Okpewho (1970), especially in The Victims, it is not just the hero who suffers crucifixion in the hands of society. In the text, the society's god is rejected and replaced with an alien one as observed when the Roman Catholic god clashes with the African goddess. The society itself, which neglects its own god, in turn suffers neglect from the god and a reign of dissatisfaction, infertility and consequent lunacy and death are enthroned.

Recurrent in all the African poems, which give a spiritual dimension to the political/economic problems of Africa is the fact that the alien gods are ill equipped in tackling African problems. In Tchicaya U-Tam'si's poetry for instance, the magnitude of devastation wrought on central Africa is achieved through the aid of the foreign gods whose values are questionable. What is clear however is that Africans made this possible through the betrayal of their own gods. This view is explicit in his poem, "Strange Agony":

We were foolish among the tender vines

and stroked the seas in order to weep

between the pine-needles

her agony my agony our agony oh virgin

but love not being a Christian virtue

I have given joy to none

my face turned to the backs of men all Christians tacitly

thrusting at me the Cross of a god betrayed whom I betray to remain faithful

to the shadow

(Poems of Black Africa 1975:74)

Hope nor salvation cannot be received from the "cross of a god betrayed" because in the African sense, it is the forces of darkness that have taken over the system because of the absence of any adequate spiritual measure. U Tam'si's advocation is a clear fidelity to "the shadow" or the pagan god. In a clearer articulation, Abubakar Gimba in Witnesses to Tears (1986) and Innocent Victims (1988) gropes for transcendence by under-playing the dimension of witchcraft in our society. Yet, in all his novels, one thing is clear and that is that witches have taken over and determine the course, albeit backwardly, of the society. However, Gimba's search for transcendence in Allah provides no illumination since he can only come up with a logic of Allah's silence:

God works in mysterious ways. But why did God allow Zaalim to mess things up so badly? ... Who was he to query God? Quickly, he asked for God's forgiveness ... God commands no one to do evils. He repeated this to himself about half a dozen times.

But Zaalim Committed evils. No ... Zaalim wanted to do evil. And God allowed him. God allowed Zaalim to exercise his freewill for a purpose.

(Innocent Victims, Emphasis mine,1986:141-2)

In an essay, "Dimensions of Sacrifice", Mowah (1992) argues that if Gimba's "for a purpose" is true, then poetic truth becomes inferior to religious banality. He further asserts that:

Certainly, religious answers do not elevate literature because they are given without the larger exemplification of insight. And what arises from Gimba's parable is not the cathechismal solution offered by Gimba through one glib character, but rather a pervading sense of evil, of the evil of ethnic rivalry, corruption, jealousy, brutality, unbridled anarchy, oppression, satanicism, etc. Yet, of illumination is the opposing goodness of honesty, simplicity, love and dedication to the cause of humanity by some people in the society. (74)

Gimba is unprepared to perceive the conflict between witchcraft and the progressive forces in 
the African society as the root of Africa's predicament. The failure of his work as a source of spiritual solution and a source of transcendence rests on that unpreparedness. Yet even his works have in a way demonstrated that witches/dark forces are the bane of modern African society. They operate at a level of consciousness, which is higher than that of the ordinary person's. This thus allows them a measure of negative pervasiveness into every dimension of order in our society. Indeed, the problem of neocolonialism in Africa is not merely a material problem. Its spiritual dimension if properly contextualized and symbolized, will show how our leaders could be prisoners of, or/and agents of dark forces. The implication of this should be frightening. It is not enough to argue that the limitations of Less Developed African Countries in relation to post modern values Oko's The Cynic (1992) demonstrates the truism that the post-colonial desire is the desire of decolonized communities for an identity. The paradox of this truth lies in the continuous production of negative identities by our leaders or by our system. Yet this paradox is the dilemma in creation for as Benedict Anderson (1983) stipulates in Imagined Communities, nationalism has always been grounded in Babel. Babel here is the printtechnology, the narrative voices through which the forces of colonialism and darkness can be subverted. Perhaps more than any genre of literature the dramatic text allows a symbolization of Babel through various national subjects identifying themselves with the characters in these voices. During (1987) sees it in "Postmodernism or post-colonialism Today" as the emergence of Nationalism (43).

The Cynic which is a dramatic text with so many voices (babel) presents us with two levels of consciousness through which we can perceive, how the forces of politics, arts and humanity operate. The quest motive defines an awakening consciousness towards the mountain (or values). It allows for the operation of invisible obstacles. In other words, the post-colonial vision in the narrative is for the discovery of lost permanent values through a journey of consciousness to a realm that is greater and superior to that of the "fierce ones" who are limited to "the eighth elevation".

APPA: From now on, there shall be no further excursion beyond the eighth elevation of thought, it is known that the one guarding the
Radiant one will not breathe heights below the ninth elevation. (67)

By an ironic sense of logic, by not transcending the eighth realm the "Fierce Ones" become the victims of their own limitation. All it requires, is to link up with the ultimate spiritual force, "to reach the ribbon of space where to" think is to act "(73). This is symbolized in "the mountain" or the twentieth elevation.

Realistically, to show that his poetic insight is not a mere abstraction, Oko opens his narrative with an evocation of the age-old African way which Okpewho and Okigbo captured in their water goddesses:

\section{Voice: HE WHO HAS DRUNK OF MY} STREAM SHALL LIVE.(10)

Agim the protagonist - visionary of the narrative had already received the power to live from the god, Kabangetende and like a true visionary, he promises to use it for good.

Agim: $\quad$... I know who gave me the power. But wait and see. I will turn

the power into manure for the crops of your children (10).

What does Agim do? In Atta's words:

First of all, the dangerous approaches to the mountain are to be ope ned up as highways ... .Along the highways to the mountain will be built great hotels with great gardens where all the herbs are planted. You can stay in any of these hotels, free of charge, walk into the garden, and eat the herbs and be cured, and cleansed, and able to see your way to the mountain. (44-5)

In other words, rejuvenate the society with great spiritual values and rapid socio-economic progress will follow. Realistically, Oko did not allow his vision to run away with his enthusiasm for change. He understood that for such lofty demands, obstacles must be present. This is captured through Appa's words when he says that they "must... make things impossible for the Radiant One" (67).

\section{CONCLUSION}

In the light of the foregoing perception the pertinent question is how do we explain modern chaos and loss of meaning in African societies? In literature, our cynicism expectedly leads us to despair and loss of faith in the structure, which underlines reality. But one thing is clear both from the thrust of this essay and from philosophy that reality is not what we think it is. Reality is 
the invisible force that shakes the very foundation of progress and fertility.

Narrative knowledge must come to the aid of scientific knowledge in post-colonial/post-modern Africa therefore in defining the actions and expressions as well as the set-rules that constitutes the social bonds. To mourn for loss of meaning in literature and in society which is the premise of post-modernism is to credit other discourses with the discovery of meaning. But this cannot be tenable in Africa, which depends on narrative knowledge for its continuous rejuvenation and redemption. Literature in Africa must help to define a consciousness, a philosophy, a religion and culture for dismantling post-modern forces of homogenous identities or forces of retrogression and infertility in Africa. Post-colonial / postmodern African discourse in conclusion must seek to assert African difference from western culture steeped in homogenous identities.

\section{REFERENCES}

Achebe, Chinua: Arrow of God. Heinemann, London (1960).

Anderson, Benedict: Imagined Communities: Reflections on the Origin and Spread of Nationalism. Verso, London (1983).

During, Simon: Postmodernism or post-colonialism today. Textual Practice, (1): 71-83 (1987).
Echeruo, Michael: The Conditioned Imagination: From Shakespeare to Conrad. Macmillan Press Ltd., London (1978).

Fanon, Frantz: The Wretched of the Earth. Hammondsworth, Middlesex (1961), Rep. (1976).

Gimba, Abubakar: Innocent Victims. Delta Publications, Enugu (1988a).

Gimba, Abubakar: Witnesses to Tears. Delta Publications, Enugu (1988b).

Glicksberg, I. Charles: Modern Literature and the Death of God. pp. 139-41. In: Religion and Modern Literature: Essays In Theory and Criticism. G.B. Tennyson and Edward .E. Ericson Jr. (Eds.). Grand Rapids. William B. Eerdmans Publishing Company, Michigan (1985).

Mowah, Frank Uche: Dimensions of Sacrifice: Abubakar Gimba's vision of Dislocations. Journal of Contemporary Poetry, 1(2): 15-24 (1992).

Mowah, Frank Uche: Towards a Stucturalist Study of African Poetry: An Examination of the Poetry of Wole Soyinka and Okot p'Bitek. Unpublished Ph.D Thesis. University of Ibadan (1989).

Okigbo, Christopher: Labyrinth. Heinemann, London (1970).

Oko, Akomaye: The Cynic. Lagos, Kraft Books, Lagos (1992).

Okpewho, Isidore: The Victims. Longmans, London (1970).

Soyinka, Wole: Myth Literature and the African World. University Press, Cambridge (1976).

U Tamsi, Tchicaya: Strange Agony. Pp. 74-76. In: Poems of Black Africa. Wole Soyinka (Ed.). Heinemann, London (1975).

Wa Thiong'O, Ngugi: Writers in Politics. Heinemann, London (1981). 